\title{
Spectral Economies in Graham Swift's Mothering Sunday: A Romance
}

\author{
Katarzyna Więckowska \\ Nicolaus Copernicus University in Toruń \\ klew@umk.pl \\ Received 6 August 2017; accepted 30 October 2017.
}

\begin{abstract}
This article employs the concepts of spectres and haunting to analyse Graham Swift's Mothering Sunday: A Romance (2016) as a commentary on (literary) history and its economy of spectres. Referring to Jacques Derrida's notions of haunting, inheritance, and time, I focus on the spectres of literary modernism and the First World War to explore the ways in which Swift's novella questions the canonical representation of modernism and revises the conventional means of writing about the past, memory, and history. The analysis of Mothering Sunday approaches the spectre as a figure of repressed otherness and a reminder of what has been excluded or silenced, so as to trace some of the ghosts that appear in the book and to underline its melancholic, spectral character. Situating Swift's novella within the context of contemporary cultural criticism, I propose to see it as a sign of a larger cultural and critical turn, where spectres have been assimilated into the structure of the everyday and where the experience of haunting has become a major expression of the present condition.
\end{abstract}

Keywords: haunting; spectres; modernism; Graham Swift; women; WWI; textuality.

What does it mean to follow a ghost? And what if this came down to being followed by it, always, persecuted perhaps by the very chase we are leading? Here again what seems to be out front, the future, comes back in advance: from the past, from the back. (Derrida, 1994, p. 10)

All the scenes. All the scenes that never occur, but wait in the wings of possibility. (Swift, 2016, p. 54)

In Specters of Marx, Jacques Derrida describes the ghost as primarily a figure of disruption whose appearance transforms the established notions of time, space, knowledge, and identity, and opens them up for a radical re-definition. The spectre is neither present 
nor absent - neither here and now, nor safely there in the past - and it blurs the distinctions between the private and the public, or the social and the individual. On a most general level, haunting is bound up with uncertainty and doubt, leading to a transformation of ways of knowing and modes of perception, and to a re-cognition of the importance of something other than the already known. The spectre introduces indeterminacy, aptly captured by the uncertainty as to whether one follows or is followed by a ghost (Derrida, 1994, p. 10), and it brings in a confusion that makes it impossible to demarcate or stabilize all types of borders, including those between object and subject, or between self and other. Haunting always takes place in the spaces in-between, "at borders, between all those 'ones' and 'others' - alive and dead, present and absent, there and not there, visible and invisible" (Wolfreys, 2010, p. 16), and it always invokes a certain outside (Blanco \& Peeren, 2013, p. 9), pointing to what has been excluded or silenced and calling forth what appears to be absent. In doing so, it destabilizes the known as well as those who know, effectively unmasking their "essential unknowing" (Davis, 2005, p. 377); when introduced - as Derrida insists it should be- - "into the very conception of a concept. Of every concept, beginning with the concepts of being and time" (Derrida, 1994, p. 161), haunting serves to underline the uncertainty and provisionality, the ultimate undecidability of any and all concepts. ${ }^{1}$

Within the spaces where spectres may appear, literature occupies a very specific place since it is both haunted - by other texts, thoughts, and histories - and haunting, through the effects it may produce on readers and other texts. In a sense, as Julian Wolfreys claims, "to tell a story is always to invoke ghosts, to open a space through which something other returns" (Wolfreys, 2002, p. 3), where the other may signify other thoughts, perceptions, states of mind, emotions, or bodies. ${ }^{2}$ One could argue, following Avery F. Gordon, that this "spectral" character of fiction is particularly visible in texts dealing with histories that have been omitted or silenced, so that " $[\mathrm{t}] \mathrm{o}$ write stories concerning exclusions and invisibilities" comes to mean, in a very literal sense, "to write ghost stories" (Gordon, 2004, p. 115). Accordingly, narratives that give voice to the silenced, or that point to the times and places that have been silenced, necessitate a re-thinking of other texts and the ways in which they have been treated and read, perhaps especially when such narratives deal with (literary) history and when they frame their stories by evoking the ghosts of other texts.

In this article, I approach Graham Swift's Mothering Sunday: A Romance (2016) as a "ghost story" which, in a manner similar to that described by Gordon, focuses on exclusions and invisibilities and conjures up an entire structure of ghosts, including textual ones, in order to comment on some important omissions and silences in modern (literary) history. Discussing some of the ghosts that appear in the novella, I focus in particular on the spectres

\footnotetext{
${ }^{1}$ For a discussion of hauntology, the spectral turn, and cognition, see "Hauntology and Cognition: Questions of Knowledge, Pasts and Futures” (2017) by Edyta Lorek-Jezińska and Katarzyna Więckowska.

${ }^{2}$ I draw here on Wolfreys's statement that fiction "becomes haunted by the work of thought and perception, turned simultaneously towards representation of another's state of mind on the one hand, and, on the other, towards the very interiority of the reader's imaginative projection" (Wolfreys, 2010, p. 10).
} 
of literary modernism and the Great War, and on the woman writer whose life story conjures them up. I read Swift's book as a commentary on literary history and its economy of spectres, and as an exploration of ways of writing about history that value the emotional and the subjective over the objective and the factual. Finally, I place Swift's portrayal of literary modernism within the context of critical accounts of contemporary culture which, in a rather uncanny manner, return to modernism to describe the present as spectral, revisited by a number of (modernist) ghosts.

Told from the perspective of a ninety-eight-year-old woman writer, Mothering Sunday offers a series of short vignettes of the $20^{\text {th }}$ century to explore the connections between private stories and public histories, and to examine the work of memory, highlighting its selective and fundamentally subjective character. The journey into Jane Fairchild's past and the moments that have formed her as a writer is marked by repetition, in particular by the returns to Mothering Sunday of $30^{\text {th }}$ March 1924, a day filled by love, loss, and books. ${ }^{3}$ In effect, the text becomes an act of prolonged remembering which lingers on moments from the past and dwells on "the scenes that never occur, but wait in the wings of possibility" (Swift, 2016 , p. 54) to become haunting reminders of unrealized potentials and different futures. Significantly, while the memories of past events and of people and places that are long gone appear in the text as spectres, these are spectres coming from a past that is already haunted by its own ghosts, as signalled by the beginning of the book, which recalls a particular day in the past and situates it against a more distant, already receding past: "Once upon a time, before the boys were killed and when there were more horses than cars, before the male servant disappeared and they made do, at Upleigh and at Beechwood, with just a cook and a maid" (p. 3). By juxtaposing the story of a woman writer against the image of public and private histories as always already driven by spectres, the book hints at its own spectral economy, signalling both the procedures of sequestering some ghosts and uncovering others, and the inevitable repetition of similar strategies in individual acts of reading.

Mothering Sunday is a Künstlerroman that recounts the life of Jane Fairchild, an acclaimed writer, who at the close of the $20^{\text {th }}$ century recalls the experiences that have turned her into an artist: her birth; a secret rendezvous with her lover on Mothering Sunday of March $30^{\text {th }}$ 1924; and her life in Oxford, where she moved in October 1924 to work as an assistant in a bookshop and where she was given her first typewriter. Out of these, Jane singles out the Sunday in March 1924 as the key moment in her transformation, the point "when she really became a writer, or had the seed of it truly planted in her" (Swift, 2016, p. 87). On this day, Paul - the heir to the Sheringhams' fortune, to be married in two weeks' time to Miss Emma Carrington Hobday, a woman of his own class - invites Jane, a maid from the neighbouring Beechwood household, to his family house, Upleigh. The invitation marks a change in their seven-year-long secret relationship and constitutes an act of transgression which violates the existing class divisions by, for example, letting the servant enter the

\footnotetext{
${ }^{3}$ The sentimental expressions bordering on kitsch illustrate the increasing importance of sentimantality and the sentimental in Swift's work, which has been revealingly discussed by Jakob Winnberg in An Aesthetics of Vulnerability: The Sentimentum and the Novels of Graham Swift (2003).
} 
house through the front door. The sense of transgressing rules is reinforced when, after their love-making, Jane is left alone in Upleigh and wanders through the house "naked, you might say, as on the day she was born" (p. 87), metaphorically taking possession of the objects placed therein and the social status they signify. Decades later, she describes the visit as a birth-like experience that made her realise "what it truly means to be put down in this world, placed, so to speak, on its extraordinary doorstep" (p. 87). The feeling of exhilaration and of something new opening before her is terminated when she returns to Beechwood and is informed by its owner, Mr Niven, that Paul has been killed in what he and others consider a car accident, but what Jane knows must have been a suicide.

As a Bildungsroman, Mothering Sunday foregrounds the relationship between the individual and the society, so that, as Steven Connor states describing this type of fiction, "society becomes visible as the enabling field of operations for the individual, and the individual as the actualisation of social possibility" (as cited in Ferrebe, 2005, p. 70). ${ }^{4}$ Accordingly, the story of Jane and Paul and their romance illustrates the ways in which personal histories are embedded within the larger social narrative, highlighting both the restrictions that the society imposes on individual development and the opening of new social possibilities. Paul's suicide and Jane's "birth" as a writer reflect a world in transition, with the two representing the dying of the old order and the emergence of the new, respectively. The sense of passing and of impending change is indicated in the title of the book, Mothering Sunday, which refers to the old custom of giving servants a day off to visit their mothers, ${ }^{5}$ and which is described in the novella as "a ritual already fading" (Swift, 2016, p. 13), whose "very reason for existing" would soon become "a historical oddity, the custom of another age" (p. 27). This aura of a receding world is sustained through Paul's attitude to his parents, whom he calls "the shower," thereby indicating their obsolescence and loss of significance, as well as through the obstinacy with which the Sheringhams and their friends continue to cling to old customs for the sake of "the same sad, wishing-the-pastback reasons" (p. 13). Most importantly, the world of 1920s Berkshire is, as Jane acknowledges, a world "in mourning" (p. 21), whose inhabitants are unable to put the past to rest and to come to terms with the losses of the Great War.

World War I has been described by numerous commentators as the first major modern crisis that radically transformed the society and culture, and that continues to influence the world up to today, obstinately refusing "to remain buried in the past" (Stevenson, 2013, p. vii). Samuel Hynes has summarised the overall effect of the war as a transformation of "the ways in which men and women thought not only about war but about the world, and about culture and its expressions" (1990, p. ix), and Randall Stevenson has argued that the war

\footnotetext{
${ }^{4}$ The choice of Bildungsroman highlights another link between literature and WWI: according to Stevenson, the senselessness of the war and the uncertainty of survival not only discouraged writers from using the Bildungsroman, but also led to its inversion into narratives following "a kind of unbildungs - an education leading not to satisfactory stability, but towards disillusion and disaster" (Stevenson, 2013, p. 75).

${ }^{5}$ Mothering Sunday has also religious connotations, as it refers to the custom of visiting one's "mother church" on the fourth Sunday in Lent.
} 
fundamentally changed the modern way of thinking, "terminating faiths in progress, modernity, and rational systems of thought which had been sustained ever since the Enlightenment in the eighteenth century" (2013, p. viii). Significantly, the war is almost unanimously seen as the event that undermined the belief in "an evolving, coherent history" (Stevenson, 2013, p. 191), replacing it by "a conception of history as discontinuous, fragmented, and subjective" (Hynes, 1990, p. 433), as continually haunted by spectres from the past that may rupture or halt its movement.

Swift's novella records the sense of a break in history and the ensuing precariousness by evoking numerous ghosts of the First World War, so that they might be seen as forming the textual core of other spectral structures that appear in the book. The local community is depicted as decimated by the war: the Nivens, for whom Jane works, have lost in the war their two sons, Philip and James, and two of the Sheringhams' boys, Dick and Freddy, were killed in France. Years after the war, in 1924, the dead boys' rooms at Beechwood are preserved as "unalterable shrines" (Swift, 2016, p. 63) where everything remains "just as it was" (p. 92), as if their owners were to return any moment, and both the Nivens and the Sheringhams keep their boys' books waiting for them in special sections of their libraries, even though the war utterly destroyed the heroic ideal of manly adventure which the novels propagate and which Paul, the survivor, describes as "the tommyrot" (p. 71). The countryside itself is filled by all-pervasive "accumulated loss and grief" (p. 92) and by ghost-like figures, so that Jane and her friend Milly the cook, allowed by Mr Niven to ride his dead sons' bicycles, become merely "the dim ghosts of Philip and James" (p. 14). Rather disturbingly, the photographs of Paul's brothers, Dick and Freddy, watch the living from their fixed position "on the dressing table in silver frames" (p. 41); they are the silent witnesses of Jane and Paul's lovemaking, and their vacant looks follow the girl as she walks naked through the house that once belonged to them (pp. 41, 56). Because Paul is the only boy left - the last of the boys - and the inheritor of what he calls "loot" (p. 3), he is to guarantee the continuity of history by providing a link with the past as the surviving brother and friend of the lost boys, and by preserving the old way of life through his future marriage with Emma Hobday. Thus, Paul's death is a blatant demonstration of the end of the old social structures and cultural patterns, and a symptom of the loss of faith in a continuous and coherent history.

Mothering Sunday foregrounds the de-realised, spectral quality of the post-war world and follows the widespread depiction of the period as "the apocalyptic moment of transition into the new" and a time of anxious uncertainty (Bradbury \& McFarlane, 1976, pp. 51, 48). The new is represented through Jane, the "orphan, maid, prostitute" (Swift, 2016, p. 20), who "would become writer . . ., would write nineteen novels . . ., would even become a 'modern writer"' (p. 130). Jane's becoming a writer is linked with the developing modernity and the changes taking place in the 1920s, including the rise of the New 
Woman and the possibilities opening before women ${ }^{6}$; it also constitutes a major act of transgression of class and gender divisions that is linked to the death of the boys, whose books Jane is allowed to read once she becomes a maid in Beechwood. These books are "[b]oys' stuff, adventure stuff" about "[p]irates and kings-in-armour, buried treasure and sailing ships" (p. 69) by writers such as H. Rider Haggard, R. L. Stevenson, R. M. Ballantyne, or G. A. Henty; they all hark "back to childhood, boyhood or gathering manhood" (p. 66), endlessly recycling the image of manly muscular Christians that was prevalent at the turn of the century and that was discredited during the war. ${ }^{7}$ In all these tales, Jane decodes the "submerged message" or "subtext" that "life itself might be an adventure" (p. 79), but also that "adventure" is a "boys' thing" that necessarily involves "going to sea - a voyage, an unknown land - as if that was the essence of adventure and what every boy wanted to do" (p. 125). Thus, reading boys' books becomes an act of transgression and re-appropriation that makes Jane, rather than Paul, the inheritor of the "loot" ; it is this that sets her on the route to become a writer and gives a different meaning to the words that she "borrows" from the opening of Stevenson's Kidnapped to start her own story: "I will begin the story of my adventures..." (pp. 71, 79).

While transgression is a key concept in the way class and gender divisions are depicted in Mothering Sunday, it is not presented as an act of rapid change, but rather as an ongoing and long-lasting process of transforming and re-writing the existing rules from within. The sense of gradual change is contained in the second part of the title, A Romance, which draws attention to the various meanings of the word and introduces an element of play with generic conventions and their gendered (and gendering) history. Mothering Sunday is explicitly a romance, as it deals with a love affair across the class divide which, according to the formula of the popular genre, should have a happy ending; indeed, during their Sunday tryst, Jane does consider the possibility that the invitation to Paul's family house may suggest that he will not marry Emma. Additionally, the chance of a happy ending is reinforced by the epigraph to the book, "You shall go to the ball!", which casts Jane as a modern Cinderella, and in the references to Snow White and the Seven Dwarfs that are

\footnotetext{
${ }^{6}$ That the possibilities are still rather limited is explicit in Jane's description of her stay in Oxford: "If she couldn't have 'gone to Oxford' in the other sense, then she became intimate with those who had. It might even be said that she moved in university 'circles' more freely and successfully than many-poor swots that they were - who were actually there. She could even pass herself off quite convincingly as that rare and frightening creature, a female undergraduate" (Swift, 2016, p. 100; emphasis in original).

${ }^{7}$ For a discussion of muscular Christianity and heroic manhood, see K. Więckowska's Spectres of Men: Masculinity, Crisis and British Literature (2014), especially pp. 121-132.

${ }^{8}$ In this respect, I disagree with critics who see in the fact that Jane reads boys' books a proof of Swift's failure to move beyond the "traditional" female protagonist. This is the stance taken by Donald Kaczvinsky, who writes that, "While Jane Fairchild is a strong, independent, and sympathetic woman who rises to the top of her profession, she finds her voice as a writer by reading boys' adventure stories and the tales of Joseph Conrad" (2016, p. 85). From my perspective, the fact that Jane educates herself on boys' books adds strength to the novella's overall critique of the inter-war period and modernism as masculine.
} 
explicit in the description of Jane's clandestine stay in Upleigh, where she eats the pie prepared for Paul and rests in his bed. Mothering Sunday, however, stresses the other, older meaning of "romance" as a class-specific type of literature dealing with marvellous adventures and heroic deeds, with its own (masculine) codes of chivalry, honour, and society. ${ }^{9}$ Revisiting these conventions in a story about a female writer stresses the importance of difference in the act of repetition and points to the feminine as what has been excluded from the very concept of heroic adventure.

By introducing the spectre into the conception of such concepts as heroism or adventure, Swift's book points to what lies outside the concepts, uncovering "what has been forcibly expunged or evacuated" (Hesford, 2005, p. 229) from them and from the system which has produced them. Conjuring up the ghosts from the past of a woman writer, Mothering Sunday playfully re-introduces those elements that have been expunged from the conceptual domain - the tactile, the sensual, the playful, the feminine. Interestingly, Jane's appearance in the masculine space of the Sheringhams' house is linked with a sexual act, thereby supplementing the intellectual with the corporeal, and binding (female) creativity with fecundity. Alone in the house, Jane feels "both more herself, more Jane Fairchild, yet also, as never before, like some visiting ghost" (Swift, 2016, p. 87), so that the day "when she really became a writer" (p. 87) is also the day when her "ghost was - had beenpalpably and unadornedly there" (p. 70), in the library reserved for upper-class men. In fact, libraries are invariably presented in the text as masculine spaces: "the point of libraries, [Jane] sometimes thought, was not the books themselves but that they preserved this hallowed atmosphere of not-to-be-disturbed male sanctuary" (p. 66), thereby making it possible "for men to disappear into and be important in, even though they had disappeared" (p. 89). This emphasis on the masculine provenance of libraries, books, and adventures mirrors the general atmosphere of the time - as Jane states, "everything had a masculine bias in 1924" (p. 126) - and also makes her intervention into the men's world more outrageous, as "few things could be more shocking than for a woman to enter a library naked. The very idea" (p. 66).

The 1920s, the time when Jane discovers that she wants to be a writer, are also regarded as the heyday of modernism, the "art of crisis" that was substantially shaped by the First World War (Bradbury \& McFarlane, 1976, pp. 21, 50), but that was also influenced by the first wave of feminism and the increasing demands for women's political, intellectual, and cultural autonomy. ${ }^{10}$ Reflecting the style of the time, Mothering Sunday adopts a number of modernist conventions, including the focus on a single day, the contrast between the private and the public sphere, the use of third-person narration and free indirect discourse, and the

\footnotetext{
${ }^{9}$ The fact that the novella mentions H. Rider Haggard's King Solomon's Mines (1885) points to another kind of romance, the imperial romance, with whose development Haggard is credited, and thus reinforces the significance of relations between literature and power, with which Swift's book is explicitly concerned.

${ }^{10}$ Sandra Gilbert and Susan Gubar analysed the connection between male modernism and feminism in the second volume of No Man's Land: The Place of the Woman Writer in the Twentieth Century (1989).
} 
emphasis on the subjective experience of time and space (Gee, 2016). Significantly, these conventions are deployed in order to draw a portrait of the artist as a young woman, thereby working to uncover the gender politics of modernism and its enclosure within the masculine, at times masculinist space. In numerous manifestos published at the beginning of the $20^{\text {th }}$ century, modernism was explicitly defined as a male movement, "virile and manly," and was contrasted with "the feminine flabbiness of nineteenth-century writing" (Mullin, 2006, p. 139). ${ }^{11}$ The connection between men and modernism was preserved in critical and educational practices throughout the $20^{\text {th }}$ century, so that in the mid-century the movement was still "unconsciously gendered masculine" (Scott, 1990, p. 2), and "a sense of Modernism as a masculinist movement" (DeKoven, 1999, p. 176) prevailed at the century's end.

Situated against such cultural and conceptual lack of mothers, the young artist in Swift's novella could be seen as "the most miserable and desperate of creatures: no clothes to her back, no roof of her own, and eating someone else's pie" (Swift, 2016, p. 74), ${ }^{12}$ if it were not for the fact that, as Jane declares, "To have no credentials at all. To be given a clean sheet, or rather, to be a clean sheet yourself" seems to be "the perfect basis for becoming a writer-particularly a writer of fiction" (p. 86; emphasis in original). Alluring as the idea of the writer as a clean sheet may be, however, it is almost immediately contradicted by Jane's explanation of her name when, claiming that "Jane is just any old girl's name," she gives examples of such "ordinary" girls as "Jane Austen, Jane Eyre, Jane Russell..." (p. 87), thereby mixing the past with the present and reality with fiction. ${ }^{13}$ This play with references may point to the fact that Jane is a good writer who knows how to manipulate her readers - as she claims, "any writer worth her salt would lead [readers] on, tease them, lead them up the garden path" (p. 132) - but it also shows that "a heritage is never natural" and that it is always heterogeneous (Derrida, 1994, pp. 168, 16), re-constructed, sometimes recovered, through the acknowledgment of the presence of spectres.

As a ghost story that focuses on invisibilities, Mothering Sunday highlights absences, especially those of (literary) mothers, and foregrounds the importance of the continual work of inheriting, as well as the responsibility for choosing what and from whom one inherits.

\footnotetext{
${ }^{11}$ Katherine Mullin illustrates the masculinist strand of modernism by quoting from "Manifesto of Futurism" (1909), where F. T. Marinetti describes the futurists as those who "will glorify war - the world's only hygienemilitarism, patriotism, the destructive gesture of freedom-bringers, beautiful ideas worth dying for, and scorn for woman," and who, together with destroying museums and libraries, "will fight moralism, feminism, every opportunistic or utilitarian cowardice" (as cited in Mullin 2006, p. 137). For the full text of the Manifesto see, for example, J. C. Taylor's Futurism (1961, pp. 124-125).

${ }^{12}$ Swift's heroine seems to repeat here Virginia Woolf's famous call for “A Room of One's Own," first expressed in Woolf's lecture delivered in 1928 and published as an essay in 1929. The need for one's own room is stressed in the novella also by the comparison made between being a maid and an orphan: "And being a maid was a little like being an orphan, since you lived in someone else's house, you didn't have a home of your own to go to" (Swift, 2016, p. 91).

${ }^{13}$ It may be interesting to note that Jane Russell, except for being a famous Hollywood actress, was the founder of the first international adoption programme in 1955.
} 
Focusing on a future writer who educates herself in libraries filled with books about boys, the novella presents inheriting as a very material practice, where how, what, and who inherits is conditioned by what a culture or a society considers worth inheriting. Significantly, the literary heritage that Jane chooses for herself comes from another orphan, Joseph Conrad, whose Youth, a Narrative she reads on the night after Paul's death. ${ }^{14}$ In the story in which Marlow, Conrad's most famous narrator, appears for the first time, Jane discovers a vision of her own future that may be, like Marlow's East, "impalpable and enslaving, like a charm, like a whispered promise of mysterious delight" (Conrad, 1946, p. 37). Yet if Conrad's protagonist finds his "vision" in the open space of the sea, Swift's heroine finds hers in libraries that are closed for maids, except for dusting; moreover, though Jane, like Marlow, is "a youth," she is nevertheless different because, as she notes, in 1924 "there was a way in which 'youth', like 'yarn', had a strongly masculine bias to it. A man could be a 'youth', but a woman?" (Swift, 2016, p. 126). By contrasting Jane with Marlow, Mothering Sunday supplements Conrad's proto-modernist study of male consciousness with an exploration of female personality, and suggests the possibility of a "female modernism" by focusing on the development of a modern woman writer. Significantly, the difference between Marlow and Jane is paralleled by that between Jane and Conrad, in whom she finds someone similar to her, yet different. While Conrad initially seems to her "just one of those boys" (p. 125), reading his books makes Jane see him as an outsider who had to cross "some impossible - impassable - barrier" and learn "to write in a whole new language" in order to become a writer (p. 129; emphasis in original). Encountering his story makes Jane realise that, like Conrad, she too must cross an impossible barrier and find a new language, that of a woman writer, "even though she had a language" (p. 129; emphasis in original).

Mothering Sunday describes Jane finding her vision, or her youth, at a time when "the century was still in its youth," but also when "[y]outh—great swathe of it —was just what the century had lost" (Swift, 2016, p. 127), thereby pointing to the paradoxical simultaneity of death and life, with each opening its own route to a different kind of future. Focusing on a writer's struggles with her past, the book points to the obligation to remember, but at the same time it presents memory as provisional and contingent, and depicts remembering as an active process through which the past may be fabricated rather than simply represented. ${ }^{15}$ The disrupted chronology and elliptical narrative of the novella work to postpone rather than give answers, and also reinforce the image of the present as filled with spectres,

\footnotetext{
${ }^{14}$ Jane discovers Conrad's book in 1924, the year of his death, a fact recorded in the novella which depicts Jane reading the writer's obituary. Although I focus here only on "Youth," which is Jane's first encounter with Conrad, Swift's heroine reads other books by the writer, including Heart of Darkness, Lord Jim, and The Secret Agent.

${ }^{15}$ In this respect, the novella echoes Conrad's "Youth," which the writer described as both "a piece of autobiography" and a "feat of memory" (as cited in Staker, 1999, p. 105); similarly to "Youth," Swift's book blurs the difference between "fictional" and "real" biography, and questions the reliability of the mechanisms of memory. For a discussion of the representation of memory and history in Conrad's "Youth," see Susan Staker's contribution to A Joseph Conrad Companion (1999, pp. 97-124).
} 
some of which may be called forth, while others may have to remain "in the wings of possibility" (Swift, 2016, p. 54). The acknowledgment of the presence of ghosts and the awareness of their role in shaping the future reflect a specifically modern condition and illustrate the early $21^{\text {st }}$-century recognition of the importance of ghosts. In many critical accounts, contemporary cultural production is described as characterised by a return to modernism, yet filtered through the prism of postmodern experience, so that, as Josh Toth argues, it may be possible to describe the present as "a period in which the 'still incomplete project of modernity' is renewed and reassessed in the wake of a postmodern "failure" (2010, p. 88). ${ }^{16}$ Thus, Nicolas Bourriaud defines contemporary culture as the period of automodernism, "a form of modernism for the $21^{\text {st }}$ century," reconfigured through globalisation, cultural nomadism, and creolisation (Bourriaud, 2009), while Alan Kirby proposes to speak of "digimodernism," or "digital modernism," that is a reaction to and a logical effect of postmodernism, and thus implicitly also of modernism, and that should be understood as "a modulated continuity more than a rupture" (Kirby, 2009, p. 1). In what constitutes perhaps the most exhaustive analysis of contemporary culture, Timotheus Vermeulen and Robin van den Akker describe the present as a constant movement and oscillation between modernism and postmodernism, so that the metamodern is neither modern nor postmodern, but always between and beyond these two (2010). What these accounts share, despite their numerous differences, is the intuition that historical and cultural change consists in returns to and repetitions of the past, or of some of its parts, so that "what seems to be out front, the future, comes back in advance: from the past, from the back" (Derrida, 1994, p. 10). This is the image of history, time, and transformation presented in Mothering Sunday, which returns to the ghost of modernism and retrieves some of its others to remind its readers that "the being of what we are is first of all inheritance, whether we like it or know it or not" (Derrida, 2016, p. 54; emphasis in original).

\section{References}

Blanco, M. P., \& Peeren, E. (2013). Introduction: Conceptualizing spectralities. In M. P. Blanco \& E. Peeren (Eds.), The spectralities reader: Ghosts and haunting in contemporary cultural theory (pp. 1-27). London, UK: Bloomsbury.

Bourriaud, N. (2009). Explain altermodern. Retrieved August 12, 2016 from http://www.tate.org.uk/whats-on/tate-britain/exhibition/altermodern/altermodern-explain-altermodern

Bradbury, M., \& McFarlane, J. (1976). The name and nature of modernism. In M. Bradbury \& J. MacFarlane (Eds.), Modernism, 1890-1930 (pp. 19-56). Harmondsworth, UK: Penguin.

Conrad, J. (1946). Youth; Heart of darkness; The end of the tether. London, UK: J. M. Dent and Sons.

\footnotetext{
${ }^{16}$ In this section, I follow Toth's proposal to see the contemporary period as spectral, and to describe epistemic changes in terms of shifts and continuities rather than ruptures $(2010, \mathrm{pp} .5,18)$.
} 
Davis, C. (2005). Hauntology, spectres and phantoms. French Studies, 59(3), 373-379. https://doi.org/10.1093/fs/kni143

DeKoven, M. (1999). Modernism and gender. In M. Levenson (Ed.), The Cambridge companion to modernism (pp. 174-193). Cambridge, UK: Cambridge University Press.

Derrida, J. (1994). Specters of Marx: The state of the debt, the work of mourning, and the new international. (P. Kamuf, Trans.). New York, NY: Routledge.

Ferrebe, A. (2005). Masculinity in male-authored fiction, 1950-2000: Keeping it up. Basingstoke, UK: Palgrave Macmillan.

Hesford, V. (2005). Feminism and its ghosts: The spectre of the feminist-as-lesbian. Feminist Theory, $6(3), 227-250$.

Hynes, S. (1990). A war imagined: The First World War and English culture. London, UK: Bodley Head.

Gee, S. (2016, April 14). Mothering Sunday by Graham Swift. New York Times. Retrieved September 18, 2016 from http://www.nytimes.com/2016/04/17/books/review/mothering-sunday-by-graham-swift.html

Gilbert, S., \& Gubar, S. (1989). No man's land: The place of the woman writer in the twentieth century. Volume 2: Sexchanges. New Haven, CT: Yale University Press.

Gordon, A. F. (2004). Ghostly matters: Haunting and the sociological imagination. Minneapolis: University of Minnesota Press.

Kaczvinsky, D. (2016). Mothering Sunday: A Romance. World Literature Today, 90(5), 85.

Kirby, A. (2009). Digimodernism: How new technologies dismantle the postmodern and reconfigure our culture. New York, NY: Continuum.

Lorek-Jezińska, E., \& Więckowska, K. 2017. Hauntology and cognition: Questions of knowledge, pasts and futures. Theoria et Historia Scientiarum, 14, 7-23. http://dx.doi.org/10.12775/ths.2017.001, 10.01.2018

Mullin, K. 2006. Modernisms and feminisms. In E. Rooney (Ed.), The Cambridge companion to feminist literary theory (pp. 136-152). Cambridge, UK: Cambridge University Press.

Scott, B. K. (1990). Introduction. In B. K. Scott (Ed.), The gender of modernism (pp. 1-18). Bloomington: Indiana University Press.

Staker, S. (1999). Youth (1902) and Tycoon (1903). In L. Orr \& T. Billy (Eds.), A Joseph Conrad companion (pp. 97-124). Westport, CT: Greenwood Press.

Stevenson, R. (2013). Literature and the Great War 1914-1918. Oxford, UK: Oxford University Press.

Swift, G. (2016). Mothering Sunday. London, UK: Scribner.

Taylor, J. C. (1961). Futurism. New York, NY: The Museum of Modern Art.

Toth, J. (2010). The passing of postmodernism: A spectroanalysis of the contemporary. Albany, NY: Suny Press.

Vermeulen, T. \& van den Akker, R. (2010). Notes on metamodernism. Journal of Aesthetics and Culture, 2(1), 1-13. http://dx.doi.org/10.3402/jac.v2i0.5677 
Więckowska, K. (2014). Spectres of men: Masculinity, crisis and British literature. Torun, Poland: Nicolaus Copernicus University Press.

Winnberg, J. (2003). An aesthetics of vulnerability: The sentimentum and the novels of Graham Swift. Göteborg, Sweden: Göteborg University.

Wolfreys, J. (2002). Victorian hauntings: Spectrality, Gothic, the uncanny and literature. Basingstoke, UK: Palgrave.

Wolfreys, J. (2010). Ghosts: Of ourselves or, drifting with Hardy, Heidegger, James, and Woolf. In M. P. Blanco \& E. Peeren (Eds.), Popular ghosts: The haunting spaces of everyday culture (pp. 318). London, UK: Continuum. 